Subscriber access provided by Caltech Library

\title{
Article
}

\section{Selective Extraction of C70 by a Tetragonal Prismatic Porphyrin Cage}

Yi Shi, Kang Cai, Hai Xiao, Zhichang Liu, Jiawang Zhou, Dengke Shen, Yunyan Qiu, Qinghui Guo, Charlotte Stern, Michael R. Wasielewski, François Diederich, William A. Goddard, and J. Fraser Stoddart

J. Am. Chem. Soc., Just Accepted Manuscript • DOI: 10.1021/jacs.8b08555 • Publication Date (Web): 28 Sep 2018

Downloaded from http://pubs.acs.org on October 1, 2018

\section{Just Accepted}

"Just Accepted" manuscripts have been peer-reviewed and accepted for publication. They are posted online prior to technical editing, formatting for publication and author proofing. The American Chemical Society provides "Just Accepted" as a service to the research community to expedite the dissemination of scientific material as soon as possible after acceptance. "Just Accepted" manuscripts appear in full in PDF format accompanied by an HTML abstract. "Just Accepted" manuscripts have been fully peer reviewed, but should not be considered the official version of record. They are citable by the Digital Object Identifier (DOI®). "Just Accepted" is an optional service offered to authors. Therefore, the "Just Accepted" Web site may not include all articles that will be published in the journal. After a manuscript is technically edited and formatted, it will be removed from the "Just Accepted" Web site and published as an ASAP article. Note that technical editing may introduce minor changes to the manuscript text and/or graphics which could affect content, and all legal disclaimers and ethical guidelines that apply to the journal pertain. ACS cannot be held responsible for errors or consequences arising from the use of information contained in these "Just Accepted" manuscripts. 


\section{Selective Extraction of $\mathrm{C}_{70}$ by a}

\section{Tetragonal Prismatic Porphyrin Cage}

Yi Shi $^{1, \#}$, Kang Cai ${ }^{1, \#}$, Hai Xiao ${ }^{2}$, Zhichang Liu ${ }^{3}$, Jiawang Zhou ${ }^{1}$, Dengke Shen ${ }^{1}$, Yunyan Qiu ${ }^{1}$, Qinghui Guo ${ }^{1}$, Charlotte Stern, ${ }^{1}$ Michael R. Wasielewski ${ }^{1}$, François Diederich ${ }^{4}$,

William A. Goddard $\mathrm{III}^{2}$, and J. Fraser Stoddart ${ }^{1,5,6, *}$

\footnotetext{
${ }^{1}$ Department of Chemistry, Northwestern University, 2145 Sheridan Road, Evanston, Illinois 60208, USA.

${ }^{2}$ Materials and Process Simulation Center, California Institute of Technology, Pasadena, California 91125, USA.

${ }^{3}$ Institute of Natural Sciences, Westlake Institute for Advanced Study, Westlake University, No. 18 Shilongshan Road, Xihu District, Hangzhou 310064, P. R. China.

${ }^{4}$ Laboratory of Organic Chemistry, ETH Zurich, Vladimir-Prelog-Weg 3, CH-8093 Zurich, Switzerland.

${ }^{5}$ Institute for Molecular Design and Synthesis, Tianjin University, Tianjin 300072, P. R. China.

${ }^{6}$ School of Chemistry, University of New South Wales, Sydney, NSW 2052, Australia.
}

*E-mail: stoddart@,northwestern.edu

\section{MAIN TEXT}

\section{*Correspondence Address}

Professor J Fraser Stoddart

Department of Chemistry

Northwestern University

2145 Sheridan Road

Evanston, IL 60208-3113 (USA)

Tel: (+1)-847-491-3793

E-Mail: stoddart@northwestern.edu 
ABSTRACT: Along with the advent of supramolecular chemistry, research on fullerene receptors based on noncovalent bonding interactions has attracted a lot of attention. Here, we present the design and synthesis of a cationic molecular cage - a cyclophane composed of two tetraphenylporphyrins, bridged face-to-face by four viologen units in a rhomboid prismatic manner. The large cavity inside the cage, as well as the favorable donor-acceptor interactions between the porphyrin panels and the fullerene guests, enables the cage to be an excellent fullerene receptor. The 1:1 host-guest complexes formed between the cage and both $\mathrm{C}_{60}$ and $\mathrm{C}_{70}$ were characterized in the solution by HRMS and NMR, UV-Vis and fluorescence spectroscopies, and confirmed in solid-state by single-crystal X-ray diffraction analyses. The results from solution studies reveal that the cage has a much stronger binding for $\mathrm{C}_{70}$ than for $\mathrm{C}_{60}$, resulting in a selective extraction of $\mathrm{C}_{70}$ from a $\mathrm{C}_{60}$-enriched fullerene mixture $\left(\mathrm{C}_{60} / \mathrm{C}_{70}=10 / 1\right)$, demonstrating the potential of the cage as an attractive receptor for fullerene separation.

\section{- INTRODUCTION}

Since their discovery ${ }^{1}$ in 1985 , fullerenes have attracted considerable attention on account of, not only their unique spheroidal ${ }^{2}$ structures, but also because of their numerous applications ${ }^{3}$ in materials science. Along with the advent ${ }^{4}$ of supramolecular chemistry, which marked a departure from the preoccupation of chemists with covalent bonds towards an understanding of the weak intermolecular interactions, research on fullerene receptors on the basis of noncovalent bonding interactions became an active area of research in the recent decades. To date, a number of covalently and supramolecularly assembled receptors, including pincer / bowl $l^{5}$ types, box / ring $^{6}$ types, and cage ${ }^{7}$ types, have been designed as hosts for fullerenes. Among them, molecular 
cages $^{8}$ with suitable cavity sizes demonstrate stronger binding to the spherically shaped fullerene guests as a result of the enhanced geometric match of these all-carbon molecules with threedimensional (3D) cavities. However, hosts, which feature both high affinity and good selectivity towards a certain fullerene homologue, are limited ${ }^{9}$ because of the geometrical similarities of the carbon spheres.

Previously, we have described the evolution ${ }^{10}$ of the $\mathbf{E x}^{\mathbf{n}} \mathbf{B o x}{ }_{\mathbf{m}}{ }^{4+}$ family, the box-like tetracationic cyclophanes consisting of two $\pi$-electron-poor bipyridinium units, which are capable of binding with various aromatic guests when the size and electronic constitution are appropriately matched. A variety of mechanically interlocked molecules ${ }^{11}$ with distinctive topological or electronic properties, as well as molecular machines, ${ }^{12}$ have been developed based on these tetracationic cyclophanes. Recently, we have extended the "two-dimensional" macrocyclic boxes into "three-dimensional" molecular cages and synthesized ${ }^{13}$ ExCage $^{6+}$ and BlueCage $^{6+}$ as powerful receptors for polycyclic aromatic hydrocarbons (PAHs). In order to extend the cationic cyclophane family and explore the limits of this chemistry, we have now introduced porphyrin units, which have been demonstrated as versatile functional units in areas such as catalysis, ${ }^{14}$ self-assembly, ${ }^{15}$ and photosynthesis, ${ }^{16}$ as new building blocks to construct a cationic porphyrin cage molecule. In addition, the use of porphyrin units will extend significantly the dimensions of the newly developed cyclophanes, thus enabling the encapsulation of large guests such as fullerenes or polyoxometalates. ${ }^{17}$ Herein, we describe how we have designed and synthesized a novel molecular cage TPPCage ${ }^{8+}$, a compound composed of two tetraphenylporphyrins bridged face-to-face by four viologen units in a rhomboid prismatic manner. The enlarged cavity inside the cage, along with their electron-rich $\pi$-conjugated porphyrin panels, enables TPPCage ${ }^{8+}$ to act as an excellent host for the fullerenes $\mathrm{C}_{60}$ and $\mathrm{C}_{70}$. 
Notably, the results of solution studies reveal that TPPCage ${ }^{8+}$ has a much stronger binding affinity for $\mathrm{C}_{70}$ than for $\mathrm{C}_{60}$, resulting in a selective extraction of $\mathrm{C}_{70}$ from a $\mathrm{C}_{60}$-enriched fullerene mixture $\left(\mathrm{C}_{60} / \mathrm{C}_{70}=10 / 1\right)$, demonstrating the potential of TPPCage $^{8+}$ as an attractive receptor for fullerene separation.

\section{- RESULTS AND DISCUSSION}

Synthesis and Characterization of $\mathbf{T P P C a g e} \bullet \mathbf{8 P F}$. Receptor $\mathrm{TPPCage}_{\mathbf{6}} 8 \mathrm{PF}_{6} \mathrm{was}_{\text {synthesized }}$ (Scheme 1) using a TBAI-catalyzed ring-closure strategy with bzTPP and $\mathbf{T B} \bullet 4 \mathbf{P F}_{6}$ as starting materials. $\mathbf{T B} \bullet 4 \mathrm{PF}_{6}$ was derived from bzTPP by substitution of the bromines with bipyridine. The synthesis overall was accomplished through $\mathrm{S}_{\mathrm{N}} 2$ reactions in three steps from commercially available starting materials. Pure $\mathbf{T P P C a g e} 8 \mathrm{PF}_{6}$ was obtained from the reaction mixture directly by collecting the precipitate, followed by counterion exchange $\left(\mathrm{NH}_{4} \mathrm{PF}_{6} / \mathrm{H}_{2} \mathrm{O}\right)$ and bypassing the use of chromatography.

TPPCage $8 \mathrm{PF}_{6}$ was characterized in solution by NMR spectroscopy. Each signal in the ${ }^{1} \mathrm{H}$ (Figure 1a) and ${ }^{13} \mathrm{C}$ NMR (Figure 1b) spectra was assigned on the basis of a series of twodimensional (2D) NMR spectra including COSY, NOESY, HSQC, and HMBC. The simplicity of the spectra concurs with the high $D_{4 h}$ symmetry expected for a tetragonal prismatic cage. In addition, HRMS shows the desired molecular ion peaks at $\mathrm{m} / z 1413.8092$ (calcd for $\mathrm{C}_{136} \mathrm{H}_{100} \mathrm{~F}_{36} \mathrm{~N}_{16} \mathrm{P}_{6}: m / z=1413.8095\left[M-2 \mathrm{PF}_{6}\right]^{2+}$ ), an observation which confirms the formation of TPPCage $8 \mathrm{PF}_{6}$.

Solid-State Characterization of TPPCage $\mathbf{T P F}_{6}$. In order to obtain the solid-state structure of the cage compound and its degree of preorganization for host-guest chemistry, single crystals were grown by slow vapor diffusion of ${ }^{i} \mathrm{Pr}_{2} \mathrm{O}$ into a solution of $\mathbf{T P P C a g e} \bullet 8 \mathrm{PF}_{6}$ in $\mathrm{MeCN}(0.6$ 
$\mathrm{mM}$ ) over the course of 4 days. The solid-state structure (Figure 2a) which is commensurate with the nanocage TPPCage ${ }^{8+}$ crystallizing in the $P 2{ }_{1} / c$ space group, consists of two parallel mesotetraphenylporphyrins linked by four viologen units. The distance between the two porphyrin panels was found to be $12.2 \AA$. In order to minimize the torsional strain and also reduce the free space, while enhancing the crystal packing density, the four meso-metaphenylene connectors to the viologen pillars are not oriented perpendicular to the porphyrin planes, but rather adopt an angle of $131^{\circ}$. Further evidence in support of the cage's prismatic structure (Figure S22) comes from a diffusion-ordered spectroscopy / nuclear magnetic resonance (DOSY NMR) experiment. DOSY NMR provides a diffusion coefficient $D$ of $2.12 \times 10^{-6} \mathrm{~cm}^{2} \mathrm{~s}^{-1}$, corresponding to a hydrodynamic diameter of $24.0 \AA$ in solution, and is commensurate with the $24.5 \AA$ diagonal distance from the meta-phenylene moiety located at the top-left corner to the other metaphenylene moiety located at the bottom-right corner present in the solid-state structure. Although the "open window" of the cage is measured to be $8.5 \AA$ (distance between two viologen units), which is slightly smaller than the van der Waals diameter $(10.1 \AA)$ of a $\mathrm{C}_{60}$ molecule, we envision that the flexibility resulting from the rotation of the corner meso-metaphenylene rings and/or the adjustment of the torsional angles encompassing the $\mathrm{CH}_{2}$ linkers will allow larger guests to be encapsulated in the cavity.

Fullerene Encapsulation - Solution Studies. The large void volume inside the cage - in addition to the well-known ${ }^{15}$ affinity of porphyrin units for fullerenes - establishes favorable donor-acceptor interactions, and ensures that the cage acts as a good fullerene receptor. The encapsulation of fullerenes occurs upon the addition of solid $\mathrm{C}_{60}$ or $\mathrm{C}_{70}$ to a solution of TPPCage $8 \mathrm{PF}_{6}$ in DMF- 
$d_{7}$, followed by sonication for $2 \mathrm{~h}$ at room temperature. The resulting 1:1 complexes were characterized in solution by HRMS, and by NMR, UV-Vis and fluorescence spectroscopies.

In the case of $\mathrm{C}_{60}$ encapsulation, HRMS reveals the desired peak at $m / z 1774.3122$, which corresponds to the $1: 1$ host-guest complex $\mathrm{C}_{60} \subset \mathbf{T P P C a g e} \bullet 8 \mathrm{PF}_{6}$ after loss of counterions (calcd. for $\left.\mathrm{C}_{196} \mathrm{H}_{100} \mathrm{~F}_{36} \mathrm{~N}_{16} \mathrm{P}_{6}: m / z=1774.3112\left[M-2 \mathrm{PF}_{6}\right]^{2+}\right)$. More evidence comes from the ${ }^{1} \mathrm{H}$ NMR spectrum $\left(\sim 1 \mathrm{mM}\right.$ solution of TPPCage $8 \mathrm{PF}_{6}$ in DMF- $\left.d_{7}\right)$, wherein (Figure $3 \mathrm{a}$ ) two sets of signals are present on account of slow host-guest exchange at room temperature. By comparison with the ${ }^{1} \mathrm{H}$ and ${ }^{13} \mathrm{C}$ NMR spectra (Figure 3) of $\mathrm{C}_{60}$ and the empty cage TPPCage• $8 \mathrm{PF}_{6}$, the spectra of the post-sonication mixture indicate clearly that one set of signals corresponds to the empty cage $\mathbf{T P P C a g e} \bullet 8 \mathrm{PF}_{6}$, while a second set of signals can be assigned to the $\mathrm{C}_{60} \subset \mathbf{T P P C a g e} \bullet 8 \mathrm{PF}_{6}$ complex. The most significant change in chemical shift occurs for the resonances $\mathrm{H}_{\mathrm{b}}$ (Figure 3a; for labeling of the cage atoms, see Figure 1) and $\mathrm{C}_{\mathrm{b}}$ (Figure $3 \mathrm{~b}$ ). As indicated by the red arrows, the ${ }^{1} \mathrm{H}$ NMR resonance for $\mathrm{H}_{\mathrm{b}}$ shifts upfield from $8.22 \mathrm{ppm}$ in the empty TPPCage $8 \mathrm{PF}_{6}$ to $7.42 \mathrm{ppm}$ in the $\mathrm{C}_{60} \subset \mathbf{T P P C a g e} \bullet 8 \mathrm{PF}_{6}$ complex, while the ${ }^{13} \mathrm{C}$ NMR resonance of $\mathrm{C}_{\mathrm{b}}$ is upfield shielded from $136.1 \mathrm{ppm}$ in the empty TPPCage• $8 \mathrm{PF}_{6}$ to $132.4 \mathrm{ppm}$ in the $\mathrm{C}_{60} \subset \mathbf{T P P C a g e} \bullet 8 \mathrm{PF}_{6}$ complex. In contrast, resonances of all other protons and carbons associated with the meta-phenylene units are not shifted to any great extent. This observation suggests that the chemical environment inside the cage is altered as a result of the encapsulation of $\mathrm{C}_{60}$ by TPPCage ${ }^{8+}$. In addition, the ${ }^{13} \mathrm{C}$ NMR resonance for $\mathrm{C}_{60}$ in the complex is also shifted upfield by approximately $4 \mathrm{ppm}$, from 144.0 to $139.9 \mathrm{ppm}$, an observation which confirms the formation of the $\mathrm{C}_{60} \subset \mathbf{T P P C a g e} \bullet 8 \mathrm{PF}_{6}$ complex. It is noteworthy that incomplete inclusion of $\mathrm{C}_{60}$ in TPPCage $^{8+}$ was observed, even when a large excess of $\mathrm{C}_{60}$ was added to a solution of TPPCage $8 \mathrm{PF}_{6}$ in DMF- $d_{7}$, This observation can be ascribed to the low concentration of $\mathrm{C}_{60}$ in 
a saturated DMF solution, precluding the possibility of driving the equilibrium towards the complete formation of the $\mathrm{C}_{60} \subset \mathbf{T P P C a g e} \bullet 8 \mathrm{PF}_{6}$ complex. This situation, however, provides us with an easy method to measure the binding constant of $\mathbf{T P P C a g e} 8 \mathrm{PF}_{6}$ with $\mathrm{C}_{60}$ directly from integration of the ${ }^{1} \mathrm{H}$ NMR spectrum of the solution containing a mixture of empty TPPCage ${ }^{8+}$ and $\mathrm{C}_{60} \subset \mathbf{T P P C a g e}^{8+}$ complex.

The concentration of $\mathrm{C}_{60}$ in the saturated DMF solution was readily measured by UV absorption spectroscopy to be $\left[\mathrm{C}_{60}\right]=1.58 \times 10^{-4} \mathrm{M}$, allowing us to obtain the concentration of free $\mathrm{C}_{60}$ guest in the solution containing the cage compound. On account of the slow-exchange between the $\mathrm{C}_{60} \subset$ TPPCage ${ }^{8+}$ complex and free TPPCage ${ }^{8+}$, signals for both the complex and empty cage are observed, allowing us to measure directly the ratio of the two components by ${ }^{1} \mathrm{H}$ NMR integration. As a consequence, the average of three integrated ratios obtained from the encapsulation of $\mathrm{C}_{60}$ using three $\mathbf{T P P C a g e} \bullet 8 \mathrm{PF}_{6}$ solutions with different absolute concentrations resulted (Table S2) in an association constant, $K_{\mathrm{a}}=(4.5 \pm 0.4) \times 10^{3} \mathrm{M}^{-1}$. This moderately weak binding is presumably attributed to the imperfect match in size between TPPCage ${ }^{8+}$ and $\mathrm{C}_{60}$ which is a little too small to fill the cage cavity.

After gaining insight into the nature of the encapsulation between TPPCage $^{8+}$ and $\mathrm{C}_{60}$, we turned our attention to the larger fullerene $C_{70}$, which we expected to form a stronger $1: 1$ complex with TPPCage ${ }^{8+}$. In contrast with $\mathrm{C}_{60}$ encapsulation, in which two sets of signals can be identified in the ${ }^{1} \mathrm{H}$ NMR spectrum (in DMF- $d_{7}$ at $298 \mathrm{~K}, \sim 1 \mathrm{mM}$ for TPPCage•8PF 6 ), only one set of signals in the case of both ${ }^{1} \mathrm{H}$ (Figure $4 \mathrm{a}$ ) and ${ }^{13} \mathrm{C}$ (Figure $4 \mathrm{~b}$ ) NMR spectra are observed. This observation suggests that all the cage receptors are saturated with $\mathrm{C}_{70}$ in slow exchange on the NMR timescale (Figure S15), indicating an enhanced affinity of the TPPCage ${ }^{8+}$ towards the fullerene. As in the case of $\mathrm{C}_{60} \subset \mathbf{T P P C a g e} \bullet 8 \mathrm{PF}_{6}$, the resonances for $\mathrm{H}_{\mathrm{b}}-$ shifted 
upfield from 8.22 to $7.65 \mathrm{ppm}$, and that for $\mathrm{C}_{\mathrm{b}}$ - shifted upfield from 136.1 to $132.8 \mathrm{ppm}$ - move the most when compared with the resonances for other protons or carbons at the corner mesophenylene units - as indicated by red arrows - an observation which suggests the chemical environment inside the cage is changed as a result of the encapsulation of $\mathrm{C}_{70}$ by $\mathrm{TPPCage} 8 \mathrm{PF}_{6}$. The encapsulation also results (Table S1) in the upfield shift of the five ${ }^{13} \mathrm{C}$ NMR signals of $\mathrm{C}_{70}$. HRMS Data gives $m / z$ 1834.3094, which corresponds to $\mathrm{C}_{70} \subset \mathbf{T P P C a g e} \bullet 8 \mathrm{PF}_{6}$ with counterion loss (calcd for $\mathrm{C}_{206} \mathrm{H}_{100} \mathrm{~F}_{36} \mathrm{~N}_{16} \mathrm{P}_{6}: m / z=1834.3112\left[M-2 \mathrm{PF}_{6}\right]^{2+}$ ), an observation which confirms the formation of the $\mathrm{C}_{70} \subset \mathbf{T P P C a g e} \bullet 8 \mathrm{PF}_{6}$ complex.

Preliminary results from ${ }^{1} \mathrm{H}$ NMR binding studies suggest that the binding constant of TPPCage $8 \mathrm{PF}_{6}$ to $\mathrm{C}_{70}$ is larger than $1.6 \times 10^{5} \mathrm{M}^{-1}$, based on the assumption that the ratio of $\mathrm{C}_{70} \subset \mathbf{T P P C a g e} \bullet 8 \mathrm{PF}_{6}$ to $\mathbf{T P P C a g e} 8 \mathrm{PF}_{6}$ is over $20 / 1$ according to the error associated with the NMR spectroscopic technique, while the concentration of $\mathrm{C}_{70}$ in a saturated DMF solution was measured as $1.2 \times 10^{-4} \mathrm{M}$ by UV-Vis absorption. Accurate measurements of the binding constant were carried out (Figure 5) by UV titration of TPPCage $8 \mathrm{PF}_{6}$ with a $\mathrm{C}_{70}$ solution in DMF. The formation of the $\mathrm{C}_{70} \subset \mathbf{T P P C a g e} \bullet 8 \mathrm{PF}_{6}$ complex is characterized by a substantial decrease in intensity at $419 \mathrm{~nm}$ and the slight red shift $(3 \mathrm{~nm})$ of the Soret band of the porphyrin in comparison with that of $\mathbf{T P P C a g e} \bullet 8 \mathrm{PF}_{6}$ itself. As a result, the binding constant was determined to be $(2.4 \pm 0.2) \times 10^{5} \mathrm{M}^{-1}$ in DMF on the basis of a 1:1 binding mode.

In addition, the fluorescence quantum yields of TPPCage $8 \mathrm{PF}_{6}, \mathrm{C}_{60} \subset \mathbf{T P P C a g e} \bullet 8 \mathrm{PF}_{6}$, and $\mathrm{C}_{70} \subset \mathbf{T P P C a g e} \cdot 8 \mathrm{PF}_{6}$ were found to be $1.20 \%, 0.48 \%$, and $0.52 \%$, respectively. The significant quenching of emission in fullerene $\subset \mathbf{T P P C a g e} \cdot 8 \mathrm{PF}_{6}$ complexes can be ascribed to the intermolecular electron transfer from the excited-state porphyrin planes to the fullerene guests, demonstrating the encapsulation of fullerenes by TPPCage $8 \mathrm{PF}_{6}$. 
On account of the shape persistency of the cage, DOSY NMR experiments (Figure S23 and S24) give identical hydrodynamic diameters for the host-guest complexes and the free cage, i.e., $24.2 \AA$ for both the $\mathrm{C}_{60} \subset \mathbf{T P P C a g e}{ }^{8+}$ and $\mathrm{C}_{70} \subset \mathbf{T P P C a g e}{ }^{8+}$ complexes - and similar $(24.0 \AA$ from DOSY) to that for the empty cage TPPCage $8 \mathrm{PF}_{6}$, indicating that the molecular entity does not change its size on addition of the fullerenes.

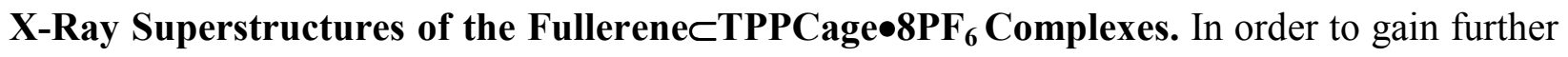
insight into the co-conformational differences between the host-guest complexes formed with $\mathrm{C}_{60}$ and $\mathrm{C}_{70}$, single crystals were grown by slow vapor diffusion of ${ }^{i} \operatorname{Pr}_{2} \mathrm{O}$ into a mixture of the fullerenes and TPPCage $8 \mathrm{PF}_{6}$ in $\mathrm{DMF} / \mathrm{PhMe}(1 / 1)$. It transpires (Figure $2 \mathrm{~b}$ and $2 \mathrm{c}$ ) that the cage is no longer oblique. In order to achieve stronger interactions with the fullerene guests, the cage becomes twisted and the two porphyrin panels form an eclipsed sandwich, trapping the carbon spheres. In the $\mathrm{C}_{60}$ complex (space group $C 2 / c$ ), the cage is a distorted tetragonal antiprismatic with an angle between the two porphrin planes of $58^{\circ}$. In the $\mathrm{C}_{70}$ complex (space group $P_{3} 21$ ), the geometry is only weakly distorted from being tetragonal antiprismatic and the angle between the two porphyrin planes is $44^{\circ}$, near the ideal $45^{\circ}$. These co-conformational changes compared to that of the free host expose a much larger surface area of the porphyrins and the viologen bridges to the fullerenes, establishing much larger $[\pi \bullet \bullet \pi]$ interactions. Notably, the twist endows the host-guest complex with axial chirality, resulting (Figure S27) in a racemic mixture upon molecular packing. X-Ray diffraction analysis also reveals that the heights of the cages in the $\mathrm{C}_{60} \subset$ TPPCage $^{8+}$ and $\mathrm{C}_{70} \subset$ TPPCage $^{8+}$ complexes only increase slightly by 0.2 and $0.5 \AA$, respectively, while the diameters of the complexes are compressed from $24.0 \AA$ (TPPCage ${ }^{8+}$ ) to $21.8 \AA\left(\mathrm{C}_{60} \subset \mathbf{T P P C a g e}^{8+}\right)$ and to $21.9 \AA\left(\mathrm{C}_{70} \subset \mathbf{T P P C a g e}{ }^{8+}\right)$. These minor differences in shape agree with DOSY NMR results, demonstrating the high degree of preorganization of this three- 
dimensional cage molecule. The distances between porphyrin panels and fullerene guests were measured as $2.64 \AA$ and $2.48 \AA$ in the cases of $\mathrm{C}_{60} \subset$ TPPCage $^{8+}$ and $\mathrm{C}_{70} \subset$ TPPCage $^{8+}$, respectively, implying strong $[\pi \cdot \cdots \pi]$ interactions between the two porphyrin platforms and the fullerenes. These distances are shorter than the normal distance $(\sim 3.4 \AA)$ for $[\pi \bullet \bullet \pi]$ stacking interactions. These shorter distances can be attributed to the hollow porphyrin panel. $[\pi \bullet \bullet \pi]$ Interactions are largely concentrated on the outer perimeters of the porphyrin macrocycles. In addition, the complex is stabilized by multiple $[\mathrm{C}-\mathrm{H} \cdots \bullet \pi]$ interactions between the fullerene guest and the protons $\mathrm{H}_{\mathrm{b}}$ pointing toward the cage cavity. The shortest fullerene-to-viologen distances were measured as $3.30 \AA$ in $\mathrm{C}_{60} \subset$ TPPCage $^{8+}$ and $2.94 \AA$ in $\mathrm{C}_{70} \subset$ TPPCage $^{8+}$, revealing that $\left[\right.$ cation $\cdots \pi$ ] interactions ${ }^{18}$ can still be operative. These short distances are actually quite remarkable as the electropositive viologen pillars and fullerene guests which also possess electropositive electrostatic potential surfaces are approaching to each other, suggesting substantial contributions from [cation $\cdots \pi]$ interactions.

It is conceivable that the superstructures of the host-guest complexes differ in the solid state and solution phases. Therefore, we carried out density functional theory (DFT) calculations in order to obtain insight into the solution-state superstructures and clarification of the preference for encapsulation of fullerenes by the cage. The DFT calculations were performed for both $\mathrm{C}_{60}$ and $\mathrm{C}_{70}$ encapsulation by the cage, employing the B3LYP functional ${ }^{19}$ with empirical D3 dispersion correction ${ }^{20}$ (B3LYP-D3), and the M06-2X functional ${ }^{21}$ that includes dispersion intrinsically. The solvation effect was taken into account using the conductor-like continuum polarization model ${ }^{22}$ (C-PCM) with DMF as the solvent. In the case of the calculated superstructures (Figure S28) of the fullerene $\subset$ TPPCage ${ }^{8+}$ DFT complexes, both B3LYP-D3 and M06-2X results confirm that the encapsulation of $\mathrm{C}_{70}$ is preferred, with the encapsulation energy 
(Table S4) being larger than that for $\mathrm{C}_{60}$ by $15.1 \mathrm{kcal} / \mathrm{mol}$ (B3LYP-D3) and $4.2 \mathrm{kcal} / \mathrm{mol}$ (M062X), respectively. The results of these calculation are consistent with the solid-state superstructures, illustrated in Figure $2 \mathrm{~b}$ and $2 \mathrm{c}$, an observation which indicates that the ellipsoidal $\mathrm{C}_{70}$ provides a larger area than the perfectly spherical $\mathrm{C}_{60}$ to form $[\pi \cdots \bullet \pi$ interactions with two porphyrin panels. In addition, the formation of the $\mathrm{C}_{70} \subset \mathbf{T P P C a g e}^{8+}$ is more thermodynamically favorable than that of $\mathrm{C}_{60} \subset \mathbf{T P P C a g e}{ }^{8+}$ because of stronger [cation $\cdots \pi \pi$ ] and $[\mathrm{C}-\mathrm{H} \cdots \pi]$ interactions between the cage and the better size-matched $\mathrm{C}_{70}$.

Selective Extraction of $\mathbf{C}_{70}$. Encouraged by the different binding affinities of $\mathbf{T P P C a g e} \bullet 8 \mathrm{PF}_{6}$ towards $\mathrm{C}_{60}$ and $\mathrm{C}_{70}$, we decided to explore the potential of TPPCage $8 \mathrm{PF}_{6}$ in the separation of $\mathrm{C}_{70}$ from $\mathrm{C}_{60}$. We used a mixture of $\mathrm{C}_{60}$ and $\mathrm{C}_{70}$ to carry out the binding competition experiments. As expected, selective complexation (Figure 6) of the cage with $\mathrm{C}_{70}$ in a $\mathrm{C}_{60}$-enriched fullerene mixture is observed. When a mixture of solid $\mathrm{C}_{60}$ and $\mathrm{C}_{70}\left(\mathrm{C}_{60} / \mathrm{C}_{70} / \mathbf{T P P C a g e \bullet} 8 \mathrm{PF}_{6}=10 / 1 / 1\right)$ was added to a DMF- $d_{7}$ solution of TPPCage $8 \mathrm{PF}_{6}(\sim 1 \mathrm{mM})$, and sonicated, the cage selectively bound with $\mathrm{C}_{70}$ to afford the $\mathrm{C}_{70} \subset \mathbf{T P P C a g e} \bullet 8 \mathrm{PF}_{6}$ complex in the solution, while $\mathrm{C}_{60}$ remained behind as a solid. From the ${ }^{1} \mathrm{H}$ and ${ }^{13} \mathrm{C}$ NMR spectra (Figures 6a and 6b), clearly all the signals correspond very well to those of $\mathrm{C}_{70} \subset \mathbf{T P P C a g e} 8 \mathrm{PF}_{6}$, an observation which demonstrates the selective binding of $\mathbf{T P P C a g e} \bullet 8 \mathrm{PF}_{6}$ to $\mathrm{C}_{70}$, facilitating the separation of $\mathrm{C}_{70}$ from a $\mathrm{C}_{60}$-enriched mixture.

\section{- CONCLUSION}

We have synthesized a covalently connected three-dimensional organic molecular cage TPPCage $8 \mathrm{PF}_{6}$ by employing a metal-free TBAI-catalyzed ring-closure strategy with porphyrin 
and viologen building blocks. The tetragonal prismatic cages possess large cavities which are capable of encapsulating fullerene guests - namely, $\mathrm{C}_{60}$ and $\mathrm{C}_{70}-$ by means of $[\pi \bullet \bullet \pi]$ (porphyrin $\bullet \bullet$ fullerene), $[\mathrm{C}-\mathrm{H} \cdots \pi](\mathrm{C}-\mathrm{H} \cdots \bullet$ fullerene), and $[$ cation $\cdots \pi]$ interactions. Host-guest binding was investigated in solution by HRMS, and by NMR, UV-Vis and fluorescence spectroscopies, while the solid-state characterization of the empty cage $\mathrm{TPPCage} 8 \mathrm{PF}_{6}$, as well as those of the host-guest complexes $\mathrm{C}_{60} \subset \mathbf{T P P C a g e} \bullet 8 \mathrm{PF}_{6}$ and $\mathrm{C}_{70} \subset \mathbf{T P P C a g e} \bullet 8 \mathrm{PF}_{6}$ were carried out by single-crystal X-ray diffraction analysis. The comparison between empty and complexed host demonstrates a high degree of geometric preorganization for fullerene complexation. The cage molecule exhibits favorable binding selectivity towards the larger, ellipsoidal $\mathrm{C}_{70}$ over the icosahedral $\mathrm{C}_{60}$, thus facilitating the selective extraction of $\mathrm{C}_{70}$ from a $\mathrm{C}_{60}$-enriched fullerene mixture $\left(\mathrm{C}_{60} / \mathrm{C}_{70}=10 / 1\right)$. The research highlights the potential application of a host-guest technology for a selective isolation process of fullerene mixtures by using precisely design host molecules.

\section{- ASSOCIATED CONTENT}

\section{Supporting Information}

Detailed synthetic procedures and characterization data for all. This information is available free of charge via the internet at http://pubs.acs.org.

\section{- AUTHOR INFORMATION}

\section{Corresponding Author}


*stoddart@,northwestern.edu

\section{Author Contributions}

\#Y.S. and K.C. contributed equally.

\section{- ACKNOWLEDGMENTS}

This research is part of the Joint Center of Excellence in Integrated Nano-Systems (JCIN) at King Abdulaziz City of Science and Technology (KACST) and Northwestern University (NU). The authors would like to thank both KACST and NU for their continued support of this research. Computational investigations were supported by the U.S. National Science Foundation under grant no. EFRI-1332411 (W.A.G. and H.X.). This work was also supported by the U.S. Department of Energy, Office of Science, Office of Basic Energy Sciences under Award DEFG02-99ER14999 (M.R.W. and J.Z.).

\section{- REFERENCES}

1. Kroto, H. W.; Heath, J. R.; O’Brien, S. C.; Curl, R. F.; Smalley, R. E. Nature 1985, 318, $162-163$.

2. (a) Krätschmer, W.; Lamb, L. D.; Fostiropoulos, K.; Huffman, D. R. Nature 1990, 347, 354-358. (b) Johnson, R. D.; Bethune, B. S.; Yannoni, C. S. Acc. Chem. Res. 1992, 25, 169-175.

3. (a) Anthopoulos, T. D.; Kooistra, F. B.; Wondergem, H. J.; Kronholm, D.; Hummelen, J. C.; de Leeuw, D. M. Adv. Mater. 2006, 18, 1679-1684. (b) Giacalone, F.; Martín, N. Chem. Rev. 2006, 106, 5136-5190. (c) Spillmann, H.; Kiebele, A.; Stöhr, M.; Jung, T. A.; Bonifazi, D.; Cheng, F.; Diederich, F. Adv. Mater. 2006, 18, 275-279. (d) Dennler, G.; Scharber, M. C.; Brabec, C. J. Adv. Mater. 2009, 21, 1323-1338. (e) Hsieh, C.-H.; Cheng, Y.-J.; Li, P.-J.; Chen, 
C.-H.; Dubosc, M.; Liang, R.-M.; Hsu, C.-S. J. Am. Chem. Soc. 2010, 132, 4887-4893. (f)

Tanaka, H.; Abe, Y.; Matsuo, Y.; Kawai, J.; Soga, I.; Sato, Y.; Nakamura, E. Adv. Mater. 2012, 24, 3521-3525. (g) Li, L.-L.; Diau, E. W.-G. Chem. Soc. Rev. 2013, 42, 291-304. (h) Mendaza, A. D. de Zerio; Melianas, A.; Rossbauer, S.; Bäcke, O.; Nordstierna, L.; Erhart, P.; Olsson, E.; Anthopoulos, T. D.; Inganäs, O.; Müller, C. Adv. Mater. 2015, 27, 7325-7331.

4. (a) Lehn, J.-M. Angew. Chem., Int. Ed. 1988, 27, 89-112. (b) Lehn, J.-M. Science 2002, 295, 2400-2403. (c) Lehn, J.-M. Angew. Chem., Int. Ed. 2013, 52, 2836-2850. (d) Lehn, J.-M. Chem. Soc. Rev. 2017, 46, 2378-2379.

5. (a) Haino, T.; Yanase, M.; Fukazawa, Y. Angew. Chem., Int. Ed. 1998, 37, 997-998. (b) Sun, D.; Tham, F. S.; Reed, C. A.; Chaker, L.; Burgess, M.; Boyd, P. D. W. J. Am. Chem. Soc. 2000, 122, 10704-10705. (c) Ayabe, M.; Ikeda, A.; Shinkai, S.; Sakamoto, S.; Yamaguchi, K. Chem. Commun. 2002, 1032-1033. (d) Sun, D.; Tham, F. S.; Reed, C. A.; Chaker, L.; Boyd, P. D. W. J. Am. Chem. Soc. 2002, 124, 6604-6612. (e) Wang, M.-X., Zhang, X.-H.; Zheng, Q.-Y. Angew. Chem., Int. Ed. 2004, 43, 838-842. (f) Wu, Z.-Q.; Shao, X.-B.; Li, C.; Hou, J.-L.; Wang, K.; Jiang, X.-K.; Li, Z.-T. J. Am. Chem. Soc. 2005, 127, 17460-17468. (g) Pérez, E. M.; Sánchez, L.; Fernández, G.; Martín, N. J. Am. Chem. Soc. 2006, 128, 7172-7173. (h) Tong, L. H.; Wietor, J.-L.; Clegg, W.; Raithby, P. R.; Pascu, S. I.; Sanders, J. K. M. Chem. Eur. J. 2008, 14, 30353044. (i) Huerta, E.; Isla, H.; Pérez, E. M.; Bo, C.; Martín, N. Mendoza, J. J. Am. Chem. Soc. 2010, 132, 5351-5353. (j) Grimm, B.; Santos, J.; Illescas, B. M.; Muñoz, A.; Guldi, D. M.; Martín, N. J. Am. Chem. Soc. 2010, 132, 17387-17389. (k) Ho, K.-H. L.; Hijazi, I.; Rivier, L.; Gautier, C.; Jousselme, B.; de Miguel, G.; Romero-Nieto, C.; Guldi, D. M.; Heinrich, B.; Donnio, B.; Campidelli, S. Chem. Eur. J. 2013, 19, 11374-11381. (1) Davis, C. M.; Lim, J. M.; Larsen, K. R.; Kim, D. S.; Sung, Y. M.; Lyons, D. M. Lynch, V. M.; Nielsen, K. A.; Jeppesen, J. O.; Kim, 
D.; Park, J. S.; Sessler, J. L. J. Am. Chem. Soc. 2014, 136, 10410-10417. (m) Álvarez, C. M.; Aullón, G.; Barbero, H.; García-Escudero, L. A.; Martínez-Pérez, C.; Martín-Álvarez, J. M.; Miguel, D. Org. Lett. 2015, 17, 2578-2581. (n) Ikemoto, K.; Kobayashi, R.; Sato, S.; Isobe, H. Org. Lett. 2017, 19, 2362-2365. (o) Ke, X.-S.; Kim, T.; Brewster, J. T.; II, Lynch, V. M.; Kim, D.; Sessler, J. L. J. Am. Chem. Soc. 2017, 139, 4627-4630.

6. (a) Atwood, J. L.; Koutsantonis, G. A.; Raston, C. L. Nature 1994, 368, 229-231. (b) Tashiro, K.; Aida, T.; Zheng, J.-Y.; Kinbara, K.; Saigo, K.; Sakamoto, S.; Yamaguchi, K. J. Am. Chem. Soc. 1999, 121, 9477-9478. (c) Kawase, T.; Tanaka, K.; Shiono, N.; Seirai, Y.; Oda, M. Angew. Chem., Int. Ed. 2004, 43, 1722-1724. (d) Shoji, Y.; Tashiro, K.; Aida, T. J. Am. Chem. Soc., 2004, 126, 6570-6571. (e) Isla, H.; Gallego, M.; Pérez, E. M.; Viruela, R.; Ortí, E.; Martín, N. J. Am. Chem. Soc. 2006, 128, 7172-7173. (f) Gil-Ramírez, G.; Karlen, S. D.; Shundo, A.; Porfyrakis, K.; Ito, Y.; Briggs, G. A. D.; Morton, J. J. L.; Anderson, H. L. Org. Lett. 2010, 12, 3544-3547. (g) Song, J.; Aratani, N.; Shinokubo, H.; Osuka, A. J. Am. Chem. Soc. 2010, 132, 16356-16357. (h) Hu, S.-Z.; Chen, C.-F. Chem. Commun. 2010, 46, 4199-4201. (i) Mulholland, A. R.; Woodward, C. P.; Langford, S. J. Chem. Commun. 2011, 47, 1494-1496. (j) Goeb, S.; Bivaud, S.; Dron, P. I.; Balandier, J.-Y. Chasa, M.; Sallé, M. Chem. Commun. 2012, 48, 31063108. (k) Kishi, N.; Akita, M.; Kamiya, M.; Hayashi, S.; Hsu, H.-F.; Yoshizawa, M. J. Am. Chem. Soc. 2013, 135, 12976-12979. (1) Wang, Q.; Zhang, C.; Noll, B. C.; Long, H.; Jin, Y.; Zhang, W. Angew. Chem., Int. Ed. 2014, 53, 10663-10667. (m) Barnes, J. C.; Dale, E. J.; Prokofjevs, A.; Narayanan, A.; Gibbs-Hall, I. C.; Juríček, M.; Stern, C. L.; Sarjeant, A. A.; Botros, Y. Y.; Stupp, S. I.; Stoddart, J. F. J. Am. Chem. Soc. 2015, 137, 2392-2399. (n) Lu, Y.; Fu, Z.-D.; Guo, Q.-H.; Wang, M.-X. Org. Lett. 2017, 19, 1590-1593. 
7. (a) Schmittel, M.; He, B.; Mal, P. Org. Lett. 2008, 10, 2513-2516. (b) Inokuma, Y.; Arai, T.; Fujita, M. Nat. Chem. 2010, 2, 780-783. (c) Mahata, K., Frischmann, P. D.; Würthner, F. J. Am. Chem. Soc. 2013, 135, 15656-15661. (d) Nakamura, T.; Ube, H.; Miyake, R.; Shionoya, M. J. Am. Chem. Soc. 2013, 135, 18790-18793. (e) Huerta, E.; Serapian, S. A.; Santos, E.; Cequier, E.; Bo, C.; de Mendoza, J. Chem. Eur. J. 2016, 22, 13496-13505. (f) Zhang, M.; Xu, H.; Wang, M.; Saha, M. L.; Zhou, Z.; Yan, X.; Wang, H.; Li, X.; Huang, F.; She, N.; Stang, P. J. Inorg. Chem. 2017, 56, 12498-12504. (g) Cui, S.; Zhuang, G.; Lu, D.; Huang, Q.; Jia, H.; Wang, Y.; Yang, S.; Du, P. Angew. Chem., Int. Ed. 2018, 57, 9330-9335. (h) Fuertes-Espinosa, C.; GómezTorres, A.; Morales-Martínez, R.; Rodríguez-Fortea, A.; García-Simón, C.; Gándara, F.; Imaz, I.; Juanhuix, J.; Maspoch, D.; Poblet, J. M.; Echegoyen, L.; Ribas, X. Angew. Chem., Int. Ed. 2018, $57,11294-11299$.

8. (a) Mastalerz, M. Angew. Chem., Int. Ed. 2010, 49, 5042-5053. (b) Zhang, G.; Mastalerz, M. Chem. Soc. Rev. 2014, 43, 1934-1947. (c) Beuerle, F.; Gole, B. Angew. Chem., Int. Ed. 2018, $57,4850-4878$.

9. (a) Huerta, E.; Metselaar, G. A.; Fragoso, A.; Santos, E.; Bo, C.; Mendoza, J. Angew. Chem., Int. Ed. 2007, 46, 202-205. (b) Zhang, C.; Wang, Q.; Long, H.; Zhang, W. J. Am. Chem. Soc. 2011, 133, 20995-21001. (c) Meng, W.; Breiner, B.; Rissanen, K.; Thoburn, J. D.; Clegg, J. K.; Nitschke, J. R. Angew. Chem., Int. Ed. 2011, 50, 3479-3483. (d) Li, M.-J.; Huang, C.-H.; Lai, C.-C.; Chiu, S.-H. Org. Lett. 2012, 14, 6146-6149. (e) García-Simón, C.; Garcia-Borràs, M.; Gómez, L.; Parella, T.; Osuna, S.; Juanhuix, J.; Imaz, I.; Maspoch, D.; Costas, M.; Ribas, X. Nat. Commun. 2014, 5, 5557-5565. (f) Yang, D.-C.; Li, M.; Chen, C.-F. Chem. Commun. 2017, 53, 9336-9339. (g) Markiewicz, G.; Jenczak, A.; Kołodziejski, M.; Holstein, J. J.; Sanders, J. K. M.; Stefankiewicz, A. R. Nat. Commun. 2017, 8, 15109-15116. 
10. (a) Barnes, J. C.; Juríček, M.; Vermeulen, N. A.; Dale, E. J.; Stoddart, J. F. J. Org. Chem. 2013, 78, 11962-11969. (b) Henkelis, J. J.; Blackburn, A. K.; Dale, E. J.; Vermeulen, N. A.; Nassar, M. S.; Stoddart, J. F. J. Am. Chem. Soc. 2015, 137, 13252-13255. (c) Frasconi, M.; Fernando, I. R.; Wu, Y.; Liu, Z.; Liu, W.-G.; Dyar, S. M.; Barin, G.; Wasielewski, M. R.; Goddard III, W. A.; Stoddart, J. F. J. Am. Chem. Soc. 2015, 137, 11057-11068. (d) Dale, E. J.; Vermeulen, N. A.; Juríček, M.; Barnes, J. C.; Young, R. M.; Wasielewski, M. R.; Stoddart, J. F. Acc. Chem. Res. 2016, 49, 262-273. (e) Dale, E. J.; Ferris, D. P.; Vermeulen, N. A.; Henkelis, J. J.; Popovs, I.; Juríček, M.; Barnes, J. C.; Schneebeli, S. T.; Stoddart, J. F. J. Am. Chem. Soc. 2016, 138, 3667-3670. (f) Gong, X.; Young, R. M.; Hartlieb, K. J.; Miller, C.; Wu, Y.; Xiao, H.; Li, P.; Hafezi, N.; Zhou, J.; Ma, L.; Cheng, T.; Goddard III, W. A.; Farha, O. K.; Hupp, J. T.; Wasielewski, M. R.; Stoddart, J. F. J. Am. Chem. Soc. 2017, 139, 4107-4116. (g) Roy, I.; Bobbala, S.; Zhou, J.; Nguyen, M. T.; Nalluri, S. K. M.; Wu, Y.; Ferris, D. P.; Scott, E. A.; Wasielewski, M. R.; Stoddart, J. F. J. Am. Chem. Soc. 2018, 140, 206-7212.

11. (a) Stoddart, J. F. Chem. Soc. Rev. 2009, 38, 1802-1820. (b) Barnes, J. C.; Frasconi, M.; Young, R. M.; Khdary, N. H.; Liu, W.-G.; Dyar, S. M.; McGonigal, P. R.; Gibbs-Hall, I. C.; Diercks, C.; Sarjeant, A. A.; Stern, C. L.; Goddard III, W. A.; Wasielewski, M. R.; Stoddart, J. F. J. Am. Chem. Soc. 2014, 136, 10569-10572. (c) Gibbs-Hall, I. C.; Vermeulen, N. A.; Dale, E. J.; Henkelis, J. J.; Blackburn, A. K.; Barnes, J. C.; Stoddart, J. F. J. Am. Chem. Soc. 2015, 137, 15640-15643. (d) Chen, Q.; Sun, J.; Li, P.; Hod, I.; Moghadem, P. Z.; Kean, Z.; Snurr, R. Q.; Hupp, J. T.; Farha, O. K.; Stoddart, J. F. J. Am. Chem. Soc. 2016, 138, 14242-14245. (e) Cheng, C.; Cheng, T.; Xiao, H.; Krzyaniak, M. D.; Wang, Y.; McGonigal, P. R.; Frasconi, M.; Barnes, J. C.; Fahrenbach, A. C.; Wasielewski, M. R.; Goddard III, W. A.; Stoddart, J. F. J. Am. Chem. Soc. 2016, 138, 8288-8300. (f) Sun, J.; Liu, Z.; Liu, W,-G.; Wu, Y.; Wang, Y.; Barnes, J. C.; 
Hermann, K. R.; Goddard III, W. A.; Wasielewski, M. R.; Stoddart, J. F. J. Am. Chem. Soc. 2017, 139, 12704-12709. (g) Lipke, M. C.; Chang, T.; Wu, Y.; Arslan, H.; Xiao, H.; Wasielewski, M. R.; Goddard III, W. A.; Stoddart, J. F. J. Am. Chem. Soc. 2017, 139, 3986-3998. (h) Gong, X.; Zhou, J.; Hartlieb, K. J.; Miller, C.; Li, P.; Farha, O. K.; Hupp, J. T.; Young, R. M.; Wasielewski, M. R.; Stoddart, J. F. J. Am. Chem. Soc. 2018, 140, 6540-6544.

12. (a) Barnes, J. C.; Fahrenbach, A. C.; Dyar, S. M.; Frasconi, M.; Giesener, M. A.; Zhu, Z.; Liu, Z.; Hartlieb, K. J.; Carmieli, R.; Wasielewski, M. R.; Stoddart, J. F. Proc. Natl. Acad. Sci. 2012, 109, 11446-11551. (b) Li, H.; Cheng, C.; McGonigal, P. R.; Fahrenbach, A. C.; Frasconi, M.; Liu, W.-G.; Zhu, Z.; Zhao, Y.; Ke, C.; Lei, J.; Young, R. M.; Dyar, S. M.; Co, D. T.; Yang, Y.-W.; Botros, Y. Y.; Goddard III, W. A.; Wasielewski, M. R.; Astumian, R. D.; Stoddart, J. F. J. Am. Chem. Soc. 2013, 135, 18609-18620. (c) Bruns, C. J.; Frasconi, M.; Iehl, J.; Hartlieb, K. J.; Schneebeli, S. T.; Cheng, C.; Stupp, S. I.; Stoddart, J. F. J. Am. Chem. Soc. 2014, 136, 47144723. (d) Cheng, C.; McGonigal, P. R.; Schneebeli, S. T.; Li, H.; Vermeulen, N. A.; Ke, C.; Stoddart, J. F. Nat. Nanotech. 2015, 10, 547-553. (e) Pezzato, C.; Nguyen, M. T.; Cheng, C.; Kim, D. J.; Otley, M. T.; Stoddart, J. F. Tetrahedron 2017, 73, 4849-4857.

13. (a) Dale, E. J.; Vermeulen, N. A.; Thomas, A. A.; Barnes, J. C.; Juríček, M.; Blackburn, A. K.; Strutt, N. L.; Sarjeant, A. A.; Stern, C. L.; Denmark, S. E.; Stoddart, J. F. J. Am. Chem. Soc. 2014, 136, 10669-10682. (b) Hafezi, N.; Holcroft, J. M.; Hartlieb, K. J.; Dale, E. J.; Vermeulen, N. A.; Stern, C. L.; Sarjeant, A. A.; Stoddart, J. F. Angew. Chem., Int. Ed. 2015, 54, $456-461$.

14. (a) Meunier, B. Chem. Rev. 1992, 92, 1411-1456. (b) Leenders, S. H. A. M.; GramageDoria, R.; de Bruin, B.; Reek, J. N. H. Chem. Soc. Rev. 2015, 44, 433-448. 
15. (a) Beletskaya, I.; Tyurin, V. S.; Tsivadze, A. Y.; Guilard, R.; Stern, C. Chem. Rev. 2009, 109, 1659-1713. (b) Drain, C. M.; Varotto, A.; Radivojevic, I. Chem. Rev. 2009, 109, 1630-1658. (c) Medforth, C. J.; Wang, Z.; Martin, K. E.; Song, Y.; Jacobsen, J. L.; Shelnutt, J. A. Chem. Commun. 2009, 47, 7261-7277. (d) Tanaka, T.; Osuka, A. Chem. Soc. Rev. 2015, 44, 943-969.

16. (a) Wasielewski, M. R. Chem. Rev. 1992, 92, 435-461. (b) Bonifazi, D.; Scholl, M.; Song, F.; Echegoyen, L.; Accorsi, G.; Armaroli, N.; Diederich, F. Angew. Chem., Int. Ed. 2003, 42, 4966-4970. (c) Benniston, A. C.; Harriman, A. Mater. Today 2008, 11, 26-34. (d) Bottari, G.; Trukhina, O.; Ince, M.; Torres, T. Coord. Chem. Rev. 2012, 256, 2453-2477.

17. (a) Wang, Y.-B.; Lin, Z. J. Am. Chem. Soc. 2003, 125, 6072-6073. (b) Boyd, P. D. W.; Reed, C. A. Acc. Chem. Res. 2005, 38, 235-242. (c) Vijayaraghavan, S.; Écija, D.; Auwärter, W.; Joshi, S.; Seufert, K.; Seitsonen, A. P.; Tashiro, K.; Barth, J. V. Nano Lett. 2012, 12, 4077-4083. (d) Zou, C.; Zhang, Z.; Xu, X.; Gong, Q.; Li, J.; Wu, C.-D. J. Am. Chem. Soc. 2012, 134, 87-90.

18. (a) Ma, J. C.; Dougherty, D. A. Chem. Rev. 1997, 97, 1303-1324. (b) Dougherty, D. A. Acc. Chem. Res. 2013, 46, 885-893.

19. (a) Lee, C.; Yang, W.; Parr, R. G. Phys. Rev. B 1988, 37, 785-789. (b) Becke, A. D. J. Chem. Phys. 1993, 98, 5648-5652.

20. (a) Grimme, S.; Antony, J.; Ehrlich, S.; Krieg, H. J. Chem. Phys. 2010, 132, 15104. (b) Grimme, S.; Ehrlich, S.; Goerigk, L. J. Comput. Chem. 2011, 32, 1456-1465.

21. Zhao, Y.; Truhlar, D. G. Theor. Chem. Acc. 2008, 120, 215-241.

22. Barone, V.; Cossi, M. J. Phys. Chem. A 1998, 102, 1995-2001. 


\section{Figure Legends}

Scheme 1 | Synthesis of TPPCage $8 \mathrm{PF}_{6}$.

Figure 1 | NMR Spectroscopic characterization of TPPCage $8 \mathrm{PF}_{6} \cdot(\mathrm{a}){ }^{1} \mathrm{H}\left(600 \mathrm{MHz}, \mathrm{DMF}-d_{7}\right.$, $298 \mathrm{~K})$ and (b) ${ }^{13} \mathrm{C}\left(125 \mathrm{MHz}, \mathrm{DMF}-d_{7}, 298 \mathrm{~K}\right) \mathrm{NMR}$ spectra of TPPCage• $8 \mathrm{PF}_{6}$.

Figure 2 | Solid-state structures of (a) TPPCage $8 \mathrm{PF}_{6}$ (top, looking in front of the mirror plane),

(b) $\mathbf{C}_{60} \subset \mathbf{T P P C a g e} \bullet 8 \mathrm{PF}_{6}$, and (c) $\mathbf{C}_{70} \subset \mathbf{T P P C a g e} \bullet 8 \mathrm{PF}_{6}$ obtained from single-crystal X-ray diffraction. $\mathrm{PF}_{6}{ }^{-}$anions and solvent molecules are omitted for the sake of clarity.

Figure 3 | NMR Spectroscopic characterization of $\mathbf{C}_{60} \subset \mathbf{T P P C a g e} 8 \mathrm{PF}_{6} \bullet$ (a) Comparison of ${ }^{1} \mathrm{H}$ $\left(600 \mathrm{MHz}, \mathrm{DMF}-d_{7}, 298 \mathrm{~K}\right) \mathrm{NMR}$ spectra of $\mathbf{T P P C a g e} \bullet 8 \mathrm{PF}_{6}$ and the encapsulation solution which contains both $\mathbf{T P P C a g e} \cdot 8 \mathrm{PF}_{6}$ and $\mathbf{C}_{60} \subset \mathbf{T P P C a g e} \bullet 8 \mathrm{PF}_{6}$. (b) Comparison of ${ }^{13} \mathrm{C}(125$ $\left.\mathrm{MHz}, \mathrm{DMF}-d_{7}, 298 \mathrm{~K}\right) \mathrm{NMR}$ spectra of free $\mathrm{C}_{60}$, TPPCage $8 \mathrm{PF}_{6}$ and the encapsulation solution which contains both $\mathbf{T P P C a g e} \bullet 8 \mathrm{PF}_{6}$ and $\mathbf{C}_{60} \subset \mathbf{T P P C a g e} \bullet 8 \mathrm{PF}_{6}$.

Figure 4 I NMR Spectroscopic characterization of $\mathbf{C}_{\mathbf{7 0}} \subset \mathbf{T P P C a g e} \bullet 8 \mathrm{PF}_{6}$. (a) Comparison of ${ }^{1} \mathrm{H}$ (600 MHz, DMF- $d_{7}, 298 \mathrm{~K}$ ) NMR spectra of $\mathbf{T P P C a g e} \bullet 8 \mathrm{PF}_{6}$ and the encapsulation solution which contains $\mathbf{C}_{70} \subset \mathbf{T P P C a g e} \bullet 8 \mathrm{PF}_{6}$. (b) Comparison of ${ }^{13} \mathrm{C}\left(125 \mathrm{MHz}, \mathrm{DMF}-d_{7}, 298 \mathrm{~K}\right) \mathrm{NMR}$ spectra of free $\mathrm{C}_{70}, \mathrm{TPPCage} 8 \mathrm{PF}_{6}$ and the encapsulation solution which contains $\mathrm{C}_{70} \subset \mathrm{TPPCage} \bullet 8 \mathrm{PF}_{6}$.

Figure $5 \mathrm{I}$ Binding constant measurements for $\mathbf{C}_{70} \subset \mathrm{TPPCage} 8 \mathrm{PF}_{6} . \quad \mathrm{UV}-\mathrm{Vis}$ spectrophotometric titration of a solution of $\mathbf{T P P C a g e} 8 \mathrm{PF}_{6}(10 \mu \mathrm{M})$ in DMF with a solution of $\mathrm{C}_{70}$ in $\mathrm{PhMe}(1 \mathrm{mM})$ in a $0.2 \mathrm{~cm}$ path cuvette. The formation of the $\mathbf{C}_{70} \subset \mathbf{T P P C a g e} \bullet 8 \mathrm{PF}_{6}$ complex is characterized by a significant decrease in intensity at $419 \mathrm{~nm}$ and a slight red shift (3 $\mathrm{nm}$ ) of the Soret band of the porphyrin. Inset: plot of $\Delta \mathrm{A} 422 \mathrm{~nm}$ vs equivalents of $\mathrm{C}_{70}$ added (A $=$ absorption). The association constant modeled with a 1:1 equilibrium is $\boldsymbol{K}_{\mathbf{C 7 0} \subset \mathbf{T P P C a g e}}=(2.4 \pm 0.2)$ $\times 10^{5} \mathrm{M}^{-1}$.

Figure 6 I Selective extraction of $\mathrm{C}_{70}$. (a) Selective extraction of $\mathrm{C}_{70}$ from a $\mathrm{C}_{60}$-enriched solid mixture upon adding a solution of TPPCage $\bullet 8 \mathrm{PF}_{6}$ in DMF- $d_{7}$. (b) ${ }^{1} \mathrm{H}\left(600 \mathrm{MHz}, \mathrm{DMF}-d_{7}, 298 \mathrm{~K}\right)$ 
and $(\mathrm{c}){ }^{13} \mathrm{C}\left(125 \mathrm{MHz}, \mathrm{DMF}-d_{7}, 298 \mathrm{~K}\right)$ NMR spectra of the fullerene extraction solution which contains only $\mathbf{C}_{70} \subset \mathbf{T P P C a g e} \bullet 8 \mathrm{PF}_{6}$. 


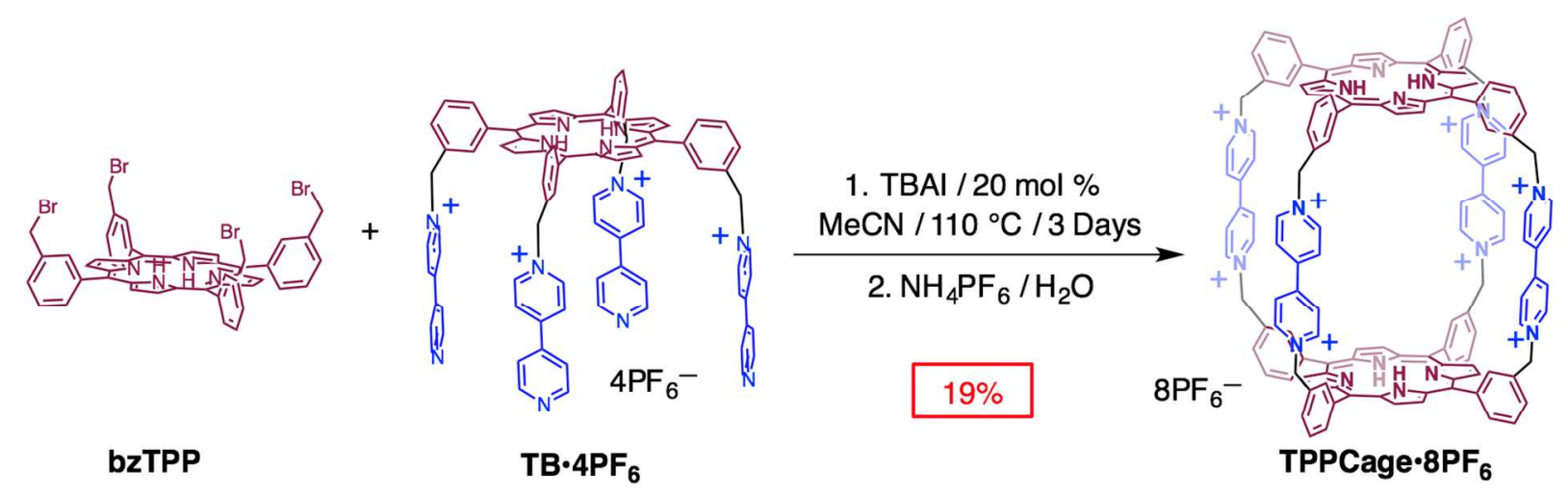

\section{Scheme 1}




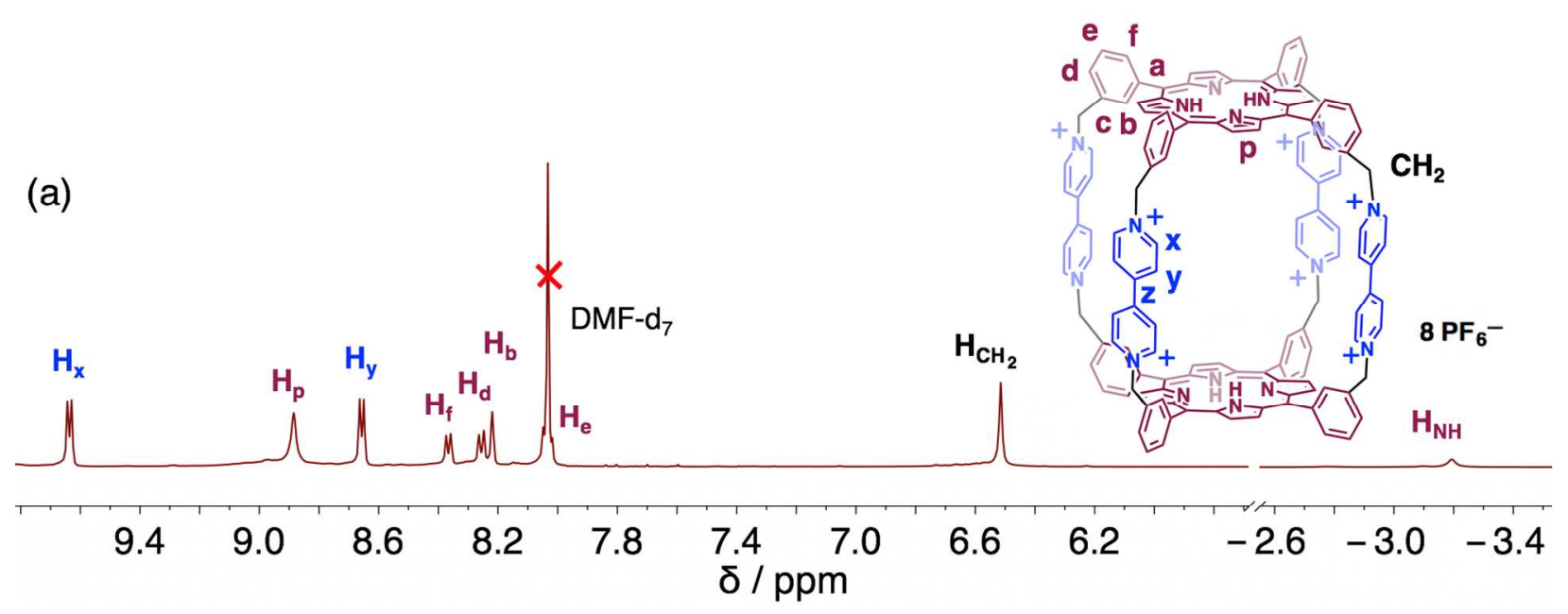

(b)

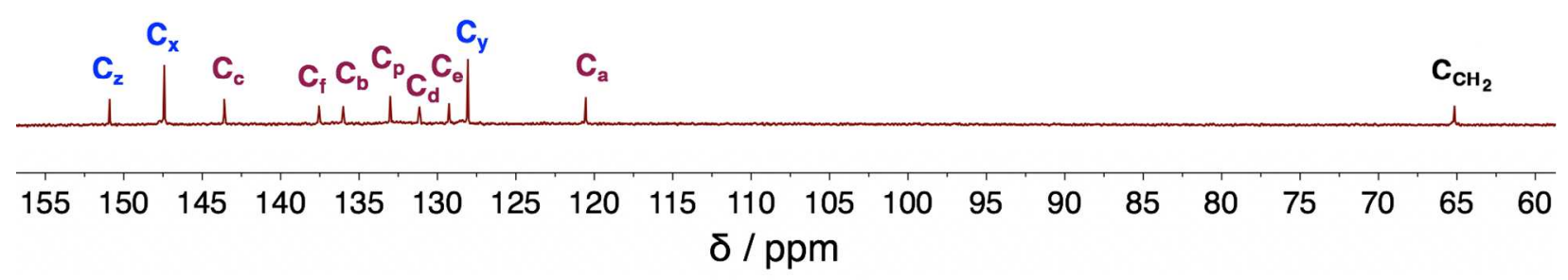

Figure 1 


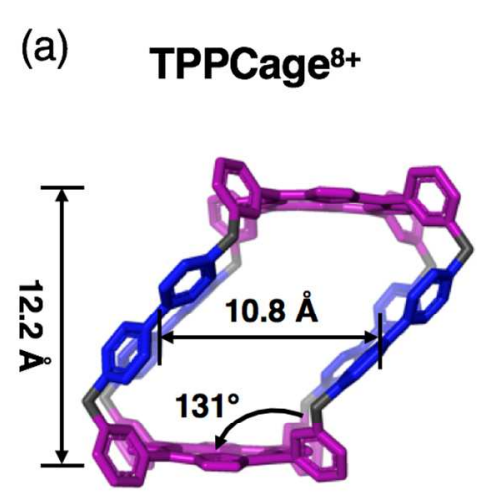

(b) $\mathbf{C}_{60} \subset$ TPPCage $^{8+}$
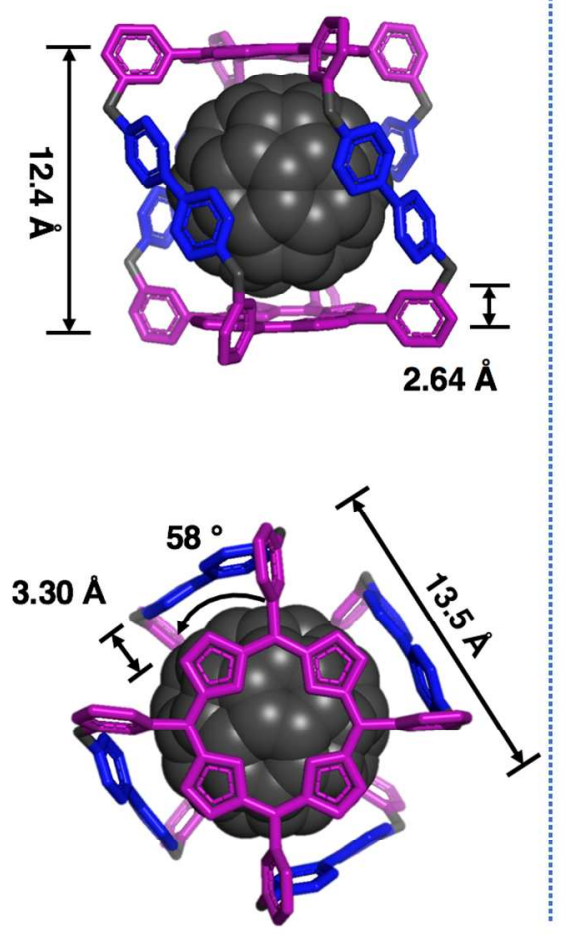

(c) C $_{70} \subset$ TPPCage $^{8+}$
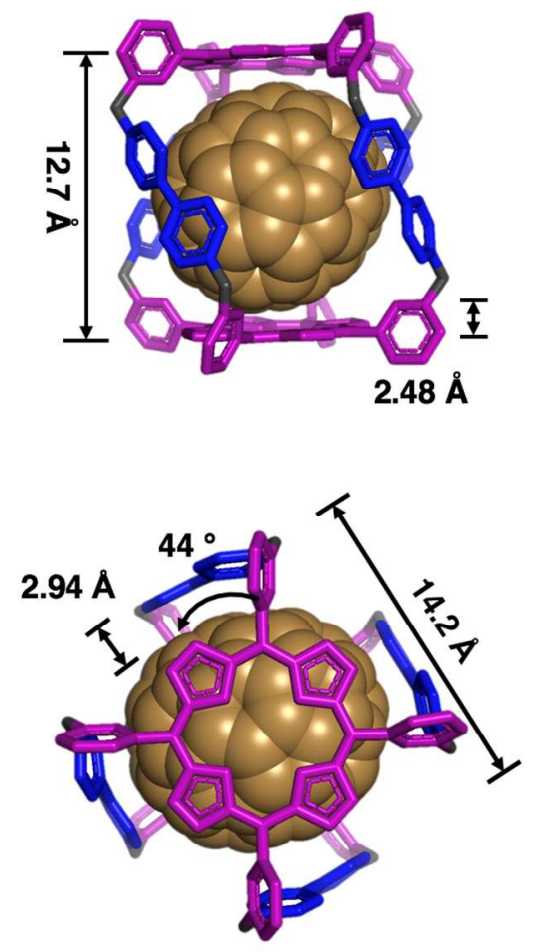

Figure 2 
(a)

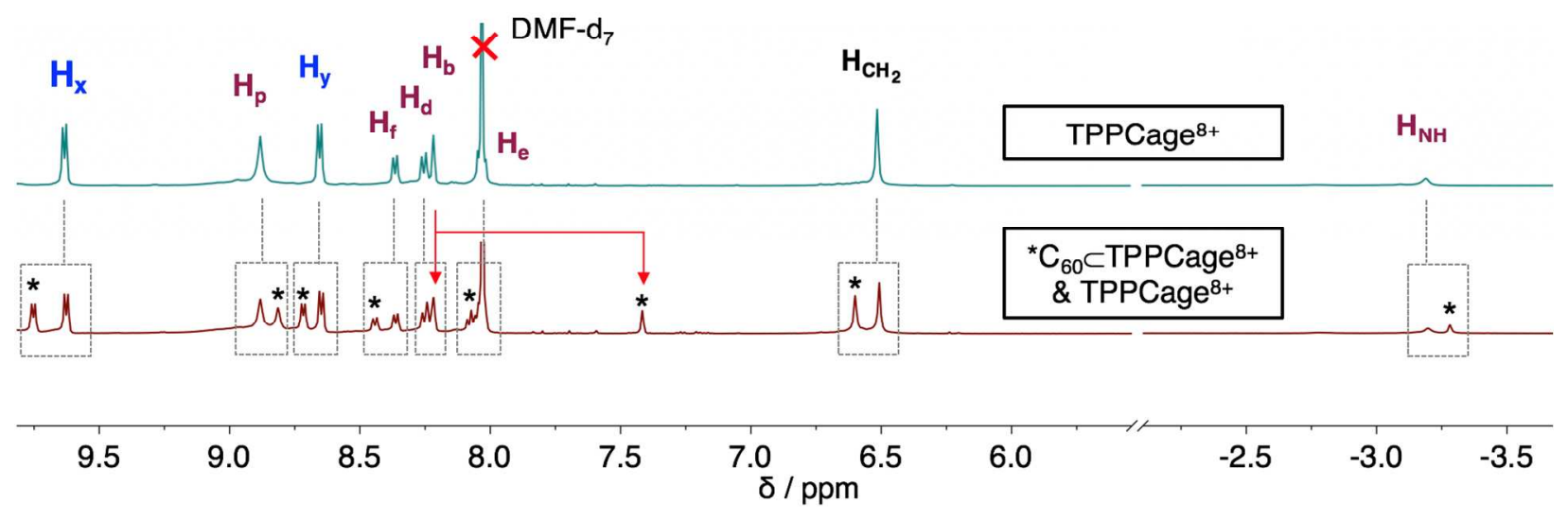

(b)
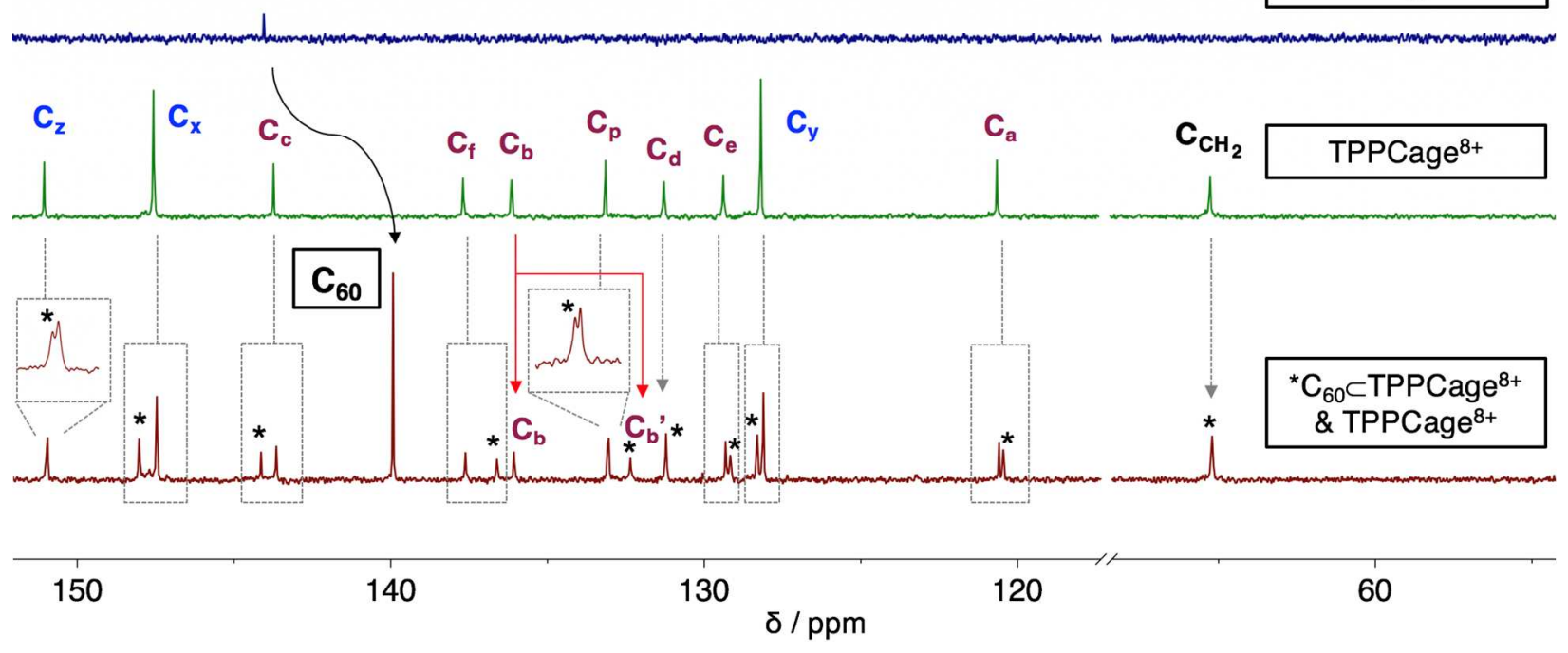

Figure 3 


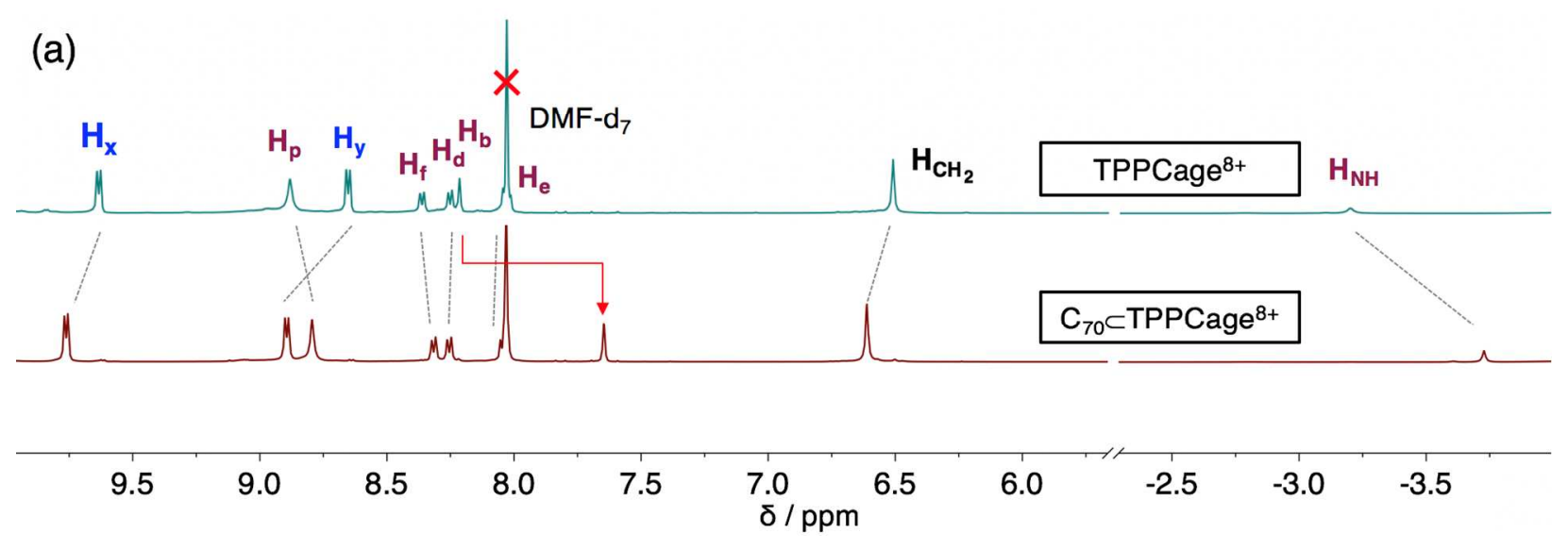

(b)

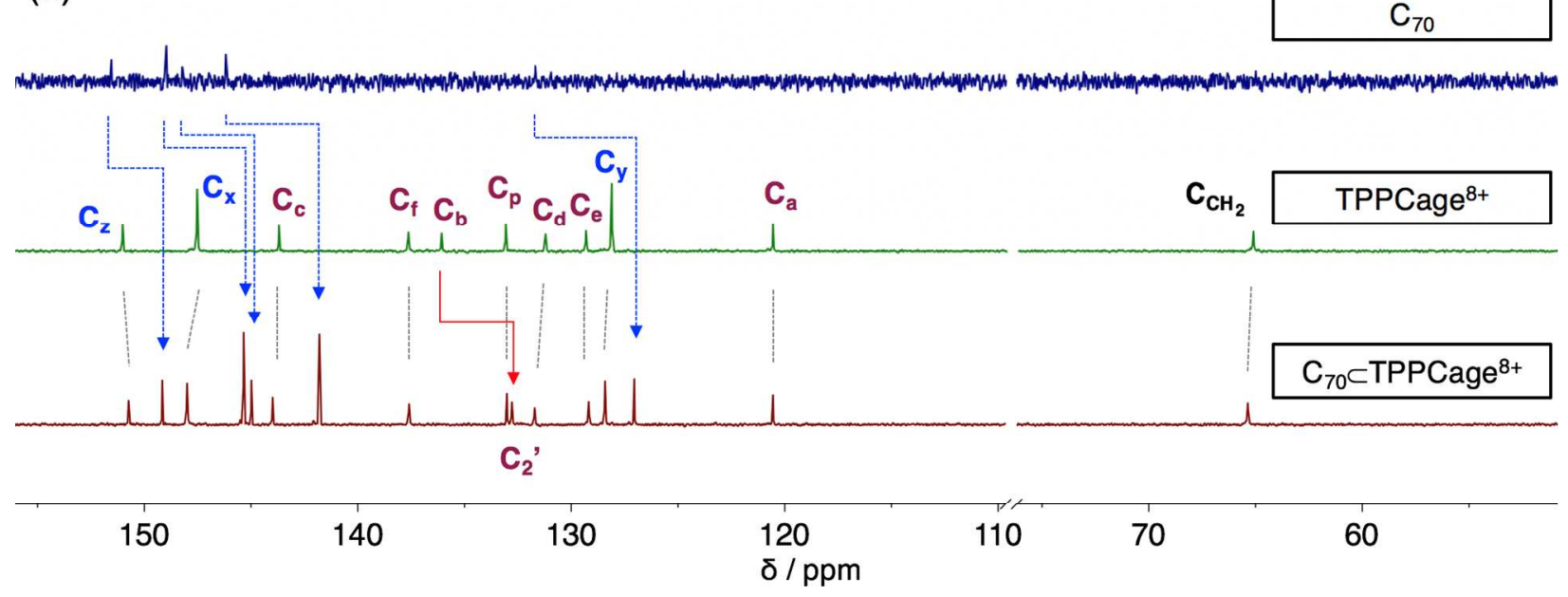

Figure 4 


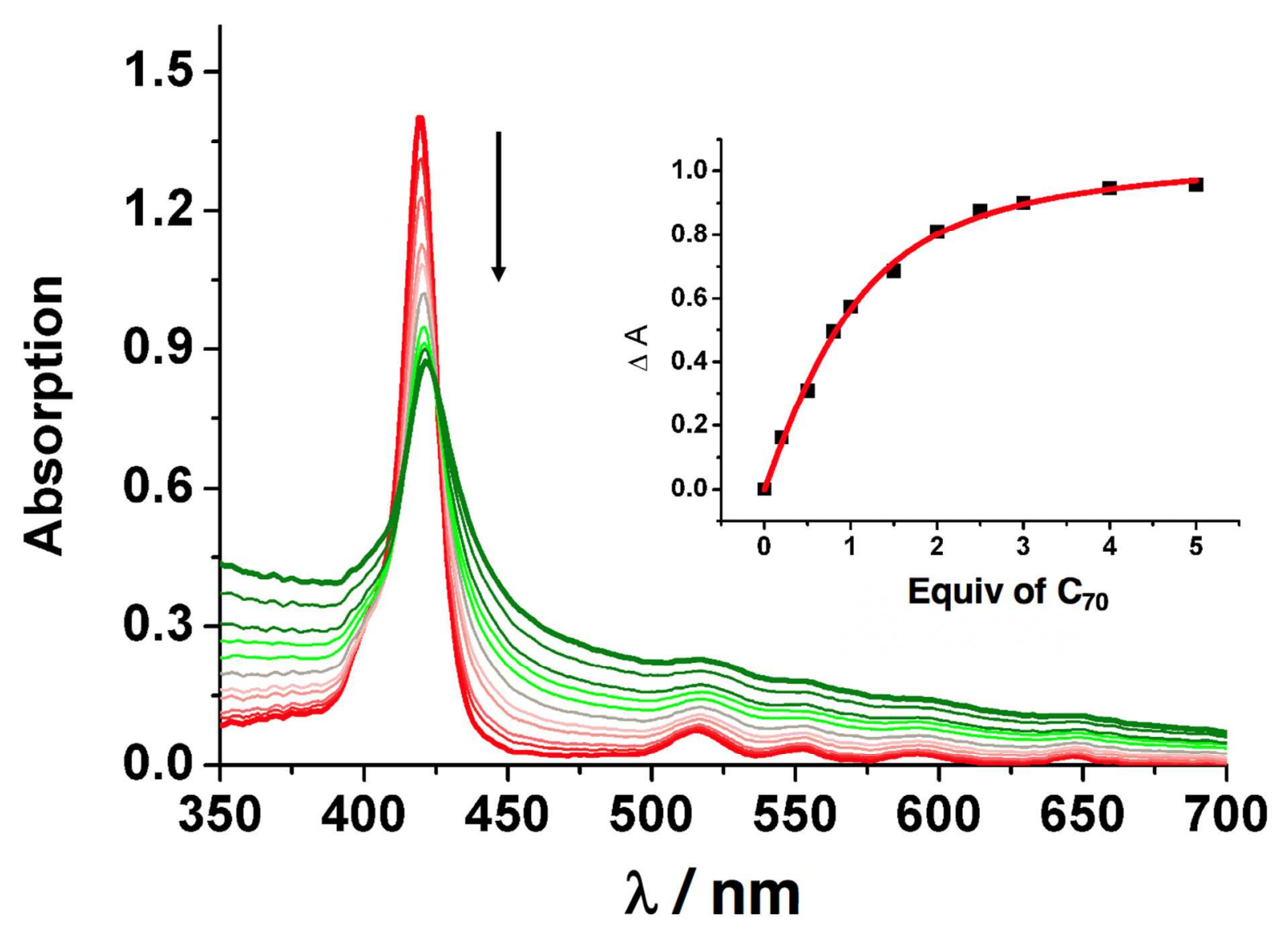

Figure 5 
(a)
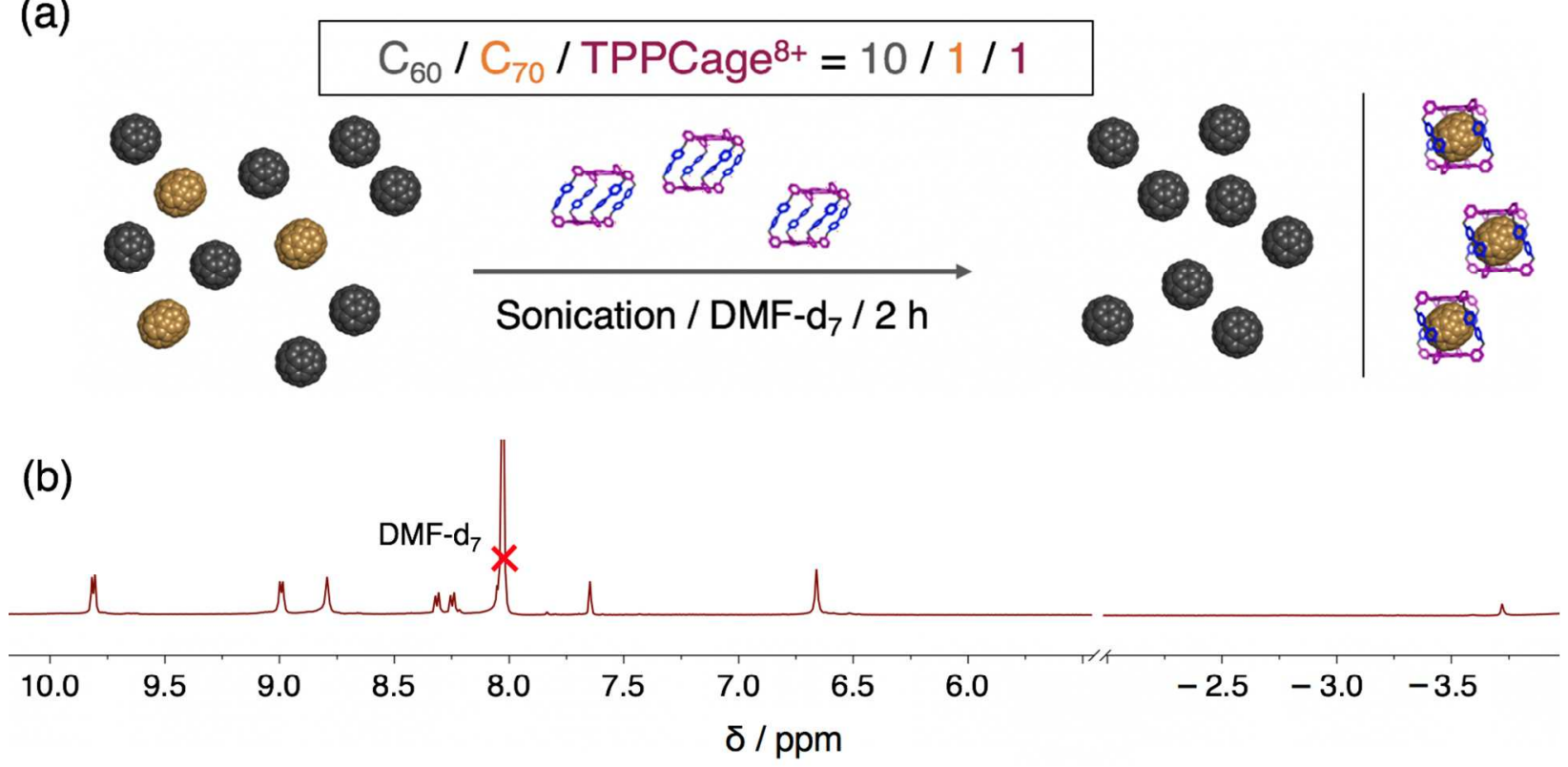

(c)

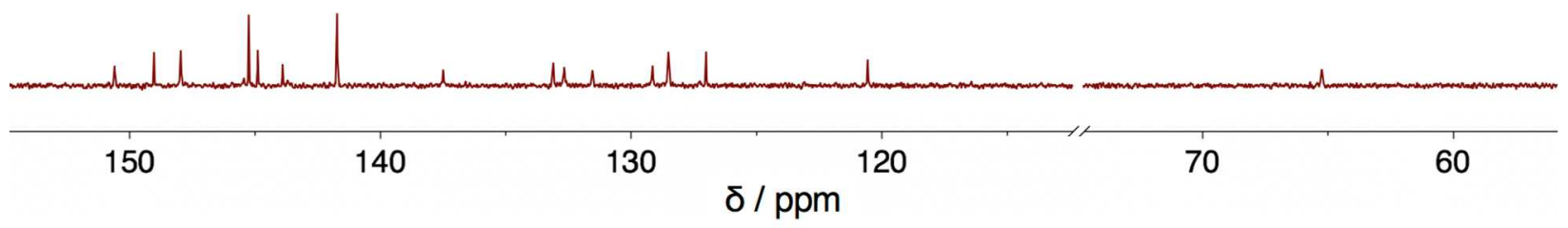

Figure 6 


\section{Table of Contents Graphic}

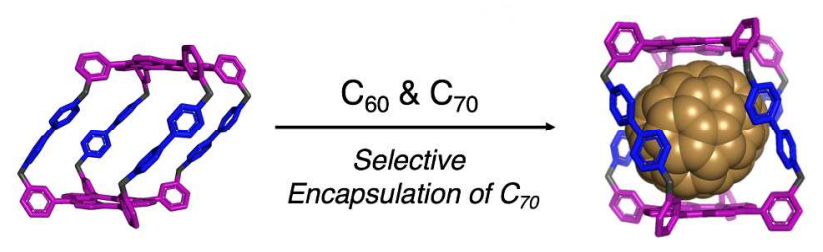

